\title{
Substrates and Temperatures in the Germination of Hibiscus sabdariffa L. Seeds
}

\author{
J. J. A. Gomes ${ }^{1}$, R. L. A. Bruno ${ }^{2}$, P. A. F. R. de Melo ${ }^{1}$, E. U. Alves ${ }^{2}$, J. R. G. Araújo ${ }^{1}$, A. P. de Andrade ${ }^{2}$, \\ R. N. V. Santos ${ }^{1}$, M. L. R. Mesquita ${ }^{3}$, M. C. S. Mendonça ${ }^{1}$ \& L. M. Barrozo ${ }^{3}$ \\ 1 Programa de Pós-Graduação em Agroecologia, Fundação de Amparo à Pesquisa e ao Desenvolvimento \\ Científico e Tecnológico do Maranhão, Universidade Estadual do Maranhão, São Luis, Maranhão, Brazil \\ ${ }^{2}$ Programa de Pós-Graduação em Agronomia, Universidade Federal Paraiba, Areia, Paraiba, Brazil \\ ${ }^{3}$ Programa de Pós-Graduação em Agricultura e Ambiente, Universidade Estadual do Maranhão, Sâo Luis, \\ Maranhão, Brazil \\ Correspondence: P. A. F. R. de Melo, Programa de Pós-Graduação em Agroecologia, Fundação de Amparo à \\ Pesquisa e ao Desenvolvimento Científico e Tecnológico do Maranhão, Universidade Estadual do Maranhão, \\ Cidade Universitária Paulo VI, S/N, 65.055-098, São Luís, Brazil. Tel: 55-16-981-018-277. E-mail: \\ pauloalexandrefernandes@outlook.com
}

Received: August 25, 2018

doi:10.5539/jas.v10n12p493
Accepted: September 29, 2018

Online Published: November 15, 2018

URL: https://doi.org/10.5539/jas.v10n12p493

\begin{abstract}
Vegetable biodiversity in Brazil accounts for almost $67 \%$ of the plants on the planet, which are part of studies with focus on determinants of food security and access to adequate and healthy food, while preserving natural resources. Studies indicate that Hibiscus sabdariffa L. is one of the most studied unconventional food crops because of its nutraceutical quality as antioxidant and prevention of hypertension and cancer. Although relevant, substrate and temperature information for seedling production of this species are scarce. Thus, the aim of this study was to evaluate the best substrate and temperature for the vigor and germination test of $H$. sabdariffa seeds of the Talo Roxo and Rubra varieties. The experiment was laid out in a randomized complete design, in a $7 \times 5$ factorial arrangement, consisting of the combinations of seven substrates (paper towel, filter paper, vermiculite, between sand, on sand, plantmax ${ }^{\circledR}$ and compost) with five temperatures $\left(20,25,30,35\right.$ and $\left.20-30{ }^{\circ} \mathrm{C}\right)$, with four replicates with 50 seeds each. The following variables were evaluated: germination, germination speed index, seedling length and dry mass. For germination and vigor tests of Hibiscus sabdariffa var. Talo Roxo seeds the paper roll substrate is recommended at temperatures of 25 or $35^{\circ} \mathrm{C}$ and for var. Rubra seeds, plantmax ${ }^{\circledR}$ at $25^{\circ} \mathrm{C}$ and plantmax ${ }^{\circledR}$ and vermiculite at temperatures of 25 or $20-30^{\circ} \mathrm{C}$, respectively.
\end{abstract}

Keywords: emergence, native species, physiological potential, seeds analysis, vigor

\section{Introduction}

Plant biodiversity of Brazil accounts for almost $67 \%$ of the plants on the planet, reinforcing the country's international role in studies on topics such as food security and access to adequate and healthy food, while preserving natural resources (Lima et al., 2016). It is estimated that $50 \%$ of the calories in the world food come from a maximum of four plant species, $90 \%$ of the food consumed comes from 103 species, but there is a potential of using at least 30 thousand plant types as food (Formagio et al., 2015). In this context, studies indicate that the use of Unconventional Food Plants (UFPs) are part of the culture, identity and agricultural practices in several regions of the world. These are represented by about 63 plant species distributed in 25 botanical families (Leal, Alves, \& Hanazaki, 2018; Barreira et al., 2015).

In recent years, Hibiscus sabdariffa L. has been among the more studied UFPs, because of its nutraceutical quality, as an antioxidant (Djaeni et al., 2018), hypertension and cancer (Riaz \& Chopra 2018) and very much discussed under food security (Guardiola \& Mach, 2014). This species belongs to the family Malvaceae and produces seeds with high protein levels $(28.9 \%)$, carbohydrates $(25.5 \%)$ and lipids $(21.4 \%)$. The main fatty acids identified are linoleic $(39.31 \%)$, oleic $(32.06 \%)$, palmitic $(20.84 \%)$ and stearic $(5.88 \%)$. Besides seeds, leaves and calyxes are widely used in cooking and traditional medicine in countries such as Mexico, India, England, 
China and Brazil (Nasrabadi, Zarringhalami, \& Ganjloo, 2018; Singh, Khan, \& Hailemariam, 2017; Nzikou et al., 20111).

Although relevant, $H$. sabdariffa cultivation is represented by a small parcel in native environments, in Brazil it occurs in areas of the Amazon biome, such as in the State of Maranhão and does not have high production (Silva, Rêgo, \& Leite, 2014). Thus, developing techniques favorable to seedling production would represent an advance in the domestication and rational exploration of $H$. sabdariffa economic potential, which is mainly obtained by extractivism and small domestic crops (Barreira et al., 2015). Information on temperature, light and substrate for nursery seedlings production is scarce (Costa et al., 2014).

The germination test is an important parameter to evaluate the seed physiological quality and allows the knowledge of seed lot physiological potential. The results of germination tests are useful to determine the rate of seedling production. However, for almost all native species, the test methodology is not yet established due to factors such as substrate and temperature (Melo et al., 2017).

For the tropical and subtropical Brazilian plant species, the optimal temperature is between 20 and $35{ }^{\circ} \mathrm{C}$, since these temperatures are the ones observed in the regions of origin of the plants, at the correct time for natural germination (Melo et al., 2017). In addition to substrate and temperature, germination is also affected by structure, air space, water retention capacity and other factors that may influence seed germination. The substrate represents the physical support on which the seed is placed with the function of offering and preserving the proper conditions of seed germination and seedling growth (Borges \& Toorop, 2015). For H. sabdariffa, there was only one report on germination, initial growth and survival of seedlings under salt stress (Galal, 2017).

The choice of substrate should be based on seed requirements at sowing, since it is a factor that can facilitate the emergence of seedlings and reduce their time in the nursery. In addition, the increase in germination speed may guarantee less deterioration in seeds with high lipid content, such as $H$. sabdariffa, because oilseeds are known to have lower viability (Jeromini et al., 2018). Thus, the aim of this study was to evaluate the best substrate and temperature for the vigor and germination test of H. sabdariffa seeds of the Talo Roxo and Rubra varieties.

\section{Material and Methods}

The present study was carried out with seeds of H. sabdariffa var. Talo Roxo and Rubra, harvested from mature fruits of ten mother plants of each variety, grown in São Luis, state of Maranhão, northeastern Brazil. Fruits from the above-mentioned varieties were collected 30 days after the anthesis, packed in polyethylene bags and taken to the Seeds Laboratory of the Agricultural Sciences Center of the Maranhão State University, São Luís Campus. The seeds were obtained by manual processing, which consisted in the removal of the fleshy calyxes for var. Talo Roxo, drying at room temperature $\left(25 \pm 3{ }^{\circ} \mathrm{C}\right)$ for 12 days and removal of the inert material by ventilation and sieves. There was no need to remove the calyxes for var. Rubra because they were dried. The seeds of each variety were homogenized for the following tests and determinations:

(1) Initial Moisture Content - test conducted by the greenhouse method at $105 \pm 3{ }^{\circ} \mathrm{C}$, for 24 hours (MAPA, 2009), using four subsamples of $1 \mathrm{~g}$ of seeds.

(2) Germination Test- test carried out in germination chambers adjusted to constant $20^{\circ} \mathrm{C}, 25{ }^{\circ} \mathrm{C}, 30{ }^{\circ} \mathrm{C}, 35{ }^{\circ} \mathrm{C}$ and alternating $20-30 \pm 3{ }^{\circ} \mathrm{C}$ temperatures and $12 \mathrm{~h} \mathrm{light} / 12 \mathrm{~h}$ dark. Four replicates of 50 seeds were sowed one $\mathrm{cm}$ deep between wet substrates of vermiculite, sand (placed between and on the substrate), compost, plantmax ${ }^{\circledR}$, two sheets of filter paper, distributed in transparent plastic boxes $(11.0 \times 11.0 \times 3.5 \mathrm{~cm})$ and also on paper rolls. The evaluations were carried out daily by counts of normal germinated seedlings, from the $5^{\text {th }}$ to the $18^{\text {th }}$ day after sowing. The results were expressed in percentage.

(3) Germination Speed Index (GSI) - performed together with the germination test with daily evaluations from the $5^{\text {th }}$ to the $18^{\text {th }}$ day after sowing. The GSI was determined by the formula proposed by Maguire (1962).

(4) Seedling Length and Dry Mass - test carried out by washing the seedlings in water to remove the substrate residue. The seedlings were measured with a ruler graduated in centimeters, the results were expressed in $\mathrm{cm}^{-1}$ seedlings. Thereafter the seedling aerial parts were separated from the roots and placed in Kraft paper bags to dry in greenhouse with forced air circulation, at $65 \pm 3{ }^{\circ} \mathrm{C}$ for 48 hours. After this time, the samples were placed to cool in a desiccator and then weighed in an analytical balance with precision of $0.0001 \mathrm{~g}$. The results were expressed in g. seedling ${ }^{-1}$ (Nakagawa, 1999).

The experiment was laid out in a randomized complete design, with the treatments distributed in a factorial scheme $7 \times 5$ (substrates and temperatures), with four replicates per treatment. The data were subjected to analyses of variance with the $\mathrm{F}$ test and the treatment means were compared by the Scott-Knott test, at 5\% probability. The statistical analyses were performed in the Statistical Analysis System (SAS) software. 


\section{Results and Discussion}

The initial water contents of $H$. sabdariffa seeds was $12.8 \%$ (data not shown in the tables). There was a significant effect $(\mathrm{p} \leq 0.05)$ of the interaction between substrates and temperatures.

The highest germination percentage of the $H$. sabdariffa var. Talo Roxo seeds was observed when paper roll was used as the substrate at temperatures of $25^{\circ} \mathrm{C}(\mathrm{G}=89 \%)$ and $35^{\circ} \mathrm{C}(\mathrm{G}=84 \%)$ respectively (Table 1), but these results did not differ statistically from those obtained on the treatments between sand at $20^{\circ} \mathrm{C}$, compost at $25{ }^{\circ} \mathrm{C}$ and on sand at $30{ }^{\circ} \mathrm{C}$. For the other combinations of substrates and temperatures, the lowest germination percentage $(\mathrm{G}=17 \%)$ was observed in compost at $20-30^{\circ} \mathrm{C}$. According to Marcos Filho (2015a), the maximum temperatures for seed germination of most plants suitable for cultivation are between 35 and $40{ }^{\circ} \mathrm{C}$.

With regards to $H$. sabdariffa var. Rubra, the highest percentage rate $(\mathrm{G}=90 \%)$ of germinated seedlings was found when plantmax ${ }^{\circledR}$ commercial substrate and the temperature of $25^{\circ} \mathrm{C}$ were combined (Table 1). However, this result was statistically similar to those obtained on paper roll at a temperature of $20{ }^{\circ} \mathrm{C}$, between sand at $20{ }^{\circ} \mathrm{C}$ and $35{ }^{\circ} \mathrm{C}$ and compost at $20-30^{\circ} \mathrm{C}$. There was also no statistical difference in germination of the seeds distributed in vermiculite at all temperatures evaluated, except at $20-30{ }^{\circ} \mathrm{C}$. The lower germinative performance was observed for seeds sown on paper at 35 and $20-30{ }^{\circ} \mathrm{C}$ and between sand at alternate temperature (Table 1).

Table 1. Germination (G\%) of H. sabdariffa L. var. Talo Roxo and var. Rubra seeds subjected to different temperatures and substrates. São Luis, state of Maranhão, northeastern Brazil, 2018

\begin{tabular}{|c|c|c|c|c|c|}
\hline \multirow{2}{*}{ Substrates } & \multicolumn{5}{|c|}{ Temperature $\left({ }^{\circ} \mathrm{C}\right)$} \\
\hline & 20 & 25 & 30 & 35 & $20-30$ \\
\hline \multicolumn{6}{|c|}{ H. sabdariffa var. Talo Roxo } \\
\hline Paper roll & $26 \mathrm{dC}$ & $89 \mathrm{aA}$ & $61 \mathrm{aB}$ & $84 \mathrm{aA}$ & $20 \mathrm{Bc}$ \\
\hline On paper & $22 \mathrm{dC}$ & $59 \mathrm{cA}$ & $21 \mathrm{cC}$ & $45 \mathrm{cB}$ & $20 \mathrm{bC}$ \\
\hline Between sand & $71 \mathrm{aA}$ & $70 \mathrm{bA}$ & $45 \mathrm{bC}$ & $59 \mathrm{bB}$ & $23 \mathrm{bD}$ \\
\hline On sand & $47 \mathrm{cA}$ & $46 \mathrm{dA}$ & $53 \mathrm{aA}$ & $34 \mathrm{~dB}$ & $39 \mathrm{aB}$ \\
\hline Plantmax $^{(B)}$ & $12 \mathrm{eC}$ & $66 \mathrm{cA}$ & $47 \mathrm{bB}$ & $48 \mathrm{cB}$ & $18 \mathrm{bC}$ \\
\hline Vermiculite & $32 \mathrm{dC}$ & $76 \mathrm{bA}$ & $27 \mathrm{cC}$ & $53 \mathrm{bB}$ & $15 \mathrm{bD}$ \\
\hline Compost & $62 \mathrm{bB}$ & $80 \mathrm{aA}$ & $45 \mathrm{bC}$ & $30 \mathrm{dD}$ & $17 \mathrm{bE}$ \\
\hline \multicolumn{6}{|c|}{ H. sabdariffa var. Rubra } \\
\hline Paper roll & $74 \mathrm{aA}$ & $65 \mathrm{bA}$ & $64 \mathrm{bA}$ & $62 \mathrm{bA}$ & $36 \mathrm{bB}$ \\
\hline On paper & $44 \mathrm{bB}$ & $63 \mathrm{bA}$ & $31 \mathrm{dC}$ & $18 \mathrm{cC}$ & $21 \mathrm{cC}$ \\
\hline Between sand & $75 \mathrm{aA}$ & $64 \mathrm{bB}$ & $62 \mathrm{bB}$ & $77 \mathrm{aA}$ & $11 \mathrm{cC}$ \\
\hline On sand & $41 \mathrm{bC}$ & $68 \mathrm{bA}$ & $64 \mathrm{bA}$ & $52 \mathrm{bB}$ & $35 \mathrm{bC}$ \\
\hline Plantmax $^{\circledR}$ & $46 \mathrm{bB}$ & $90 \mathrm{aA}$ & $49 \mathrm{cB}$ & $49 \mathrm{bB}$ & $52 \mathrm{aB}$ \\
\hline Vermiculite & $67 \mathrm{aA}$ & $80 \mathrm{aA}$ & $80 \mathrm{aA}$ & $74 \mathrm{aA}$ & $48 \mathrm{aB}$ \\
\hline Compost & $50 \mathrm{bA}$ & $36 \mathrm{cB}$ & $59 \mathrm{bA}$ & $54 \mathrm{bA}$ & $52 \mathrm{aA}$ \\
\hline $\mathrm{CV}(\%)$ & \multicolumn{3}{|c|}{ var. Talo Roxo 10.11} & abra 10. & \\
\hline
\end{tabular}

Note. Means followed by the same letter (lowercase in the column and uppercase in the row) do not differ by the Scott-Knott test at 5\% probability.

Based on these results, it can be inferred that the substrate and the temperature influence in the seed germination, because, to start this process, seeds undergo metabolic reactions that involve the activation of enzymes, hydrolysis, assimilation and mobilization of the reserves, and cell division (Melo et al., 2017). Thus, in addition to the physiological activities that vary according to the initial seed quality (Mbofung et al., 2013), the substrate structure, its water retention capacity, aeration and temperature adequacy also contribute to a higher germination percentage (Silva et al., 2016).

The results obtained in this study agree with those reported by Silva et al. (2016), who also evaluated germination of oleaginous seeds, such as Plukenetia volubilis L., where the maximum germination percentage occurred after sowing on paper roll at $25{ }^{\circ} \mathrm{C}$. However, Jeromini et al. (2018) reported that the maximum germination rate of $P$. volubilis seeds, as occurred with those of $H$. sabdariffa L. var. Talo Roxo (paper roll, $\mathrm{G}=$ 
$89 \%$ ) and var. Rubra (plantmax ${ }^{\circledR}, \mathrm{G}=90 \%$ ) depends on the progeny, the substrate and the room temperature during the sowing period, with germination performance varying from 75 to $100 \%$.

The best physiological performance of the H. sabdariffa var. Talo Roxo seeds, evaluated by the germination speed index (GSI) (Table 2), was associated to the interaction between sowing in a paper roll at 25 and $35^{\circ} \mathrm{C}$, although it was not significantly different for the GSI evaluated at the same temperature in the vermiculite substrate. These values also did not differ from those obtained for the GSI evaluated by the combination between the temperatures of 20 and $20-30{ }^{\circ} \mathrm{C}$, with the plantmax ${ }^{\circledR}$, compost and sand substrates, respectively (Table 2).

With regards to $H$. sabdariffa var. Rubra, the best GSI performance was observed when seeds were submitted to 20 and $30{ }^{\circ} \mathrm{C}$ in all substrates, except plantmax ${ }^{\circledR}$ and paper roll at 20 and $30{ }^{\circ} \mathrm{C}$, respectively (Table 2). These results did not show statistical differences of the GSI at the temperature of $25{ }^{\circ} \mathrm{C}$ in the substrates on sand, plantmax ${ }^{\circledR}$, vermiculite and at $35^{\circ} \mathrm{C}$ for the sowing done between sand and in vermiculite, as well as at $20-30{ }^{\circ} \mathrm{C}$ in all the substrates, except on paper and sand (Table 2).

Table 2. Germination speed index (GSI) of H. sabdariffa var. Talo Roxo and var. Rubra seeds, subjected to different temperatures and substrates. São Luis, state of Maranhão, northeastern Brazil, 2018

\begin{tabular}{|c|c|c|c|c|c|}
\hline \multirow{2}{*}{ Substrates } & \multicolumn{5}{|c|}{ Temperatures $\left({ }^{\circ} \mathrm{C}\right)$} \\
\hline & 20 & 25 & 30 & 35 & $20-30$ \\
\hline \multicolumn{6}{|c|}{ H. sabdariffa var. Talo Roxo } \\
\hline Paper roll & $3.04 \mathrm{bC}$ & $8.35 \mathrm{aA}$ & $6.08 \mathrm{aB}$ & $8.97 \mathrm{aA}$ & $2.38 \mathrm{aC}$ \\
\hline On paper & $2.13 \mathrm{bB}$ & $5.85 \mathrm{bA}$ & $2.02 \mathrm{cB}$ & $5.18 \mathrm{cA}$ & $3.61 \mathrm{aB}$ \\
\hline Between sand & $4.05 \mathrm{aB}$ & $5.71 \mathrm{bA}$ & $3.79 \mathrm{bB}$ & $6.69 \mathrm{bA}$ & $2.78 \mathrm{aB}$ \\
\hline On sand & $3.39 \mathrm{bA}$ & $3.90 \mathrm{bA}$ & $4.04 \mathrm{bA}$ & $2.32 \mathrm{dA}$ & $3.24 \mathrm{aA}$ \\
\hline Plantmax ${ }^{\circledR}$ & $4.72 \mathrm{aA}$ & $5.93 \mathrm{bA}$ & $3.90 \mathrm{bB}$ & $3.91 \mathrm{cB}$ & $2.24 \mathrm{aB}$ \\
\hline Vermiculite & $2.00 \mathrm{bC}$ & $7.16 \mathrm{aA}$ & $1.96 \mathrm{cC}$ & $5.07 \mathrm{cB}$ & $1.59 \mathrm{aC}$ \\
\hline Compost & $5.03 \mathrm{aA}$ & $6.08 \mathrm{bA}$ & $4.28 \mathrm{bA}$ & $2.31 \mathrm{~dB}$ & $3.11 \mathrm{aB}$ \\
\hline \multicolumn{6}{|c|}{ H. sabdariffa var. Rubra } \\
\hline Paper roll & $5.76 \mathrm{aA}$ & $6.00 \mathrm{bA}$ & $6.08 \mathrm{aA}$ & $6.09 \mathrm{bA}$ & $6.08 \mathrm{aA}$ \\
\hline On paper & $6.20 \mathrm{aA}$ & $6.53 \mathrm{bA}$ & $3.77 \mathrm{bB}$ & $1.59 \mathrm{cB}$ & $2.25 \mathrm{bB}$ \\
\hline Between sand & $6.42 \mathrm{aA}$ & $6.01 \mathrm{bA}$ & $6.83 \mathrm{aA}$ & $7.58 \mathrm{aA}$ & $1.82 \mathrm{bB}$ \\
\hline On sand & $6.42 \mathrm{aA}$ & $7.56 \mathrm{aA}$ & $6.25 \mathrm{aA}$ & $5.26 \mathrm{bA}$ & $6.50 \mathrm{aA}$ \\
\hline Plantmax $^{\circledR}$ & $5.76 \mathrm{aB}$ & $9.33 \mathrm{aA}$ & $6.90 \mathrm{aA}$ & $3.49 \mathrm{cB}$ & $8.29 \mathrm{aA}$ \\
\hline Vermiculite & $8.50 \mathrm{aA}$ & $7.64 \mathrm{aA}$ & $8.96 \mathrm{aA}$ & $8.57 \mathrm{aA}$ & $6.88 \mathrm{aA}$ \\
\hline Compost & $6.43 \mathrm{aA}$ & $3.73 \mathrm{cB}$ & $6.65 \mathrm{aA}$ & $6.25 \mathrm{bA}$ & $7.44 \mathrm{aA}$ \\
\hline $\mathrm{CV}(\%)$ & \multicolumn{2}{|c|}{ var. Talo Roxo 10.55} & \multicolumn{2}{|c|}{ var. Rubra 10.69} & \\
\hline
\end{tabular}

Note. Means followed by the same letter (lowercase in the column and uppercase in the row) do not differ by the Scott-Knott test at $5 \%$ probability.

The decrease in the GSI of the seeds subjected to $35^{\circ} \mathrm{C}$ can be caused by damage to their structure, because high temperatures inhibit the speed of embryonic development and cause enzymatic alterations, thus modifying the speed of metabolic reactions (Borges \& Toorop, 2015). However, in addition to temperature, the humidity of the substrate where sowing is performed is one of the essential factors, since, during this process, water absorption has the function of promoting the softening of the seed coat, the increase of the embryo and the reserve tissues, favoring tegument rupture, gas diffusion and the primary root growth (Marcos Filho, 2015b).

There are substrates that are used to standardize the seed germination test and others favor seedling production, all with some advantages and disadvantages. For example, some substrates can easily dry, particularly at higher temperatures (Melo et al., 2016). Paper rolls are indicated in germination tests by the rules of the Brazilian seed analysis (MAPA, 2009), because they remain moist for a longer period of time. Probably the results obtained with this substrate in this study for G\% and GSI for the var. Talo Roxo (Tables 1 and 2) are due to the interaction between the temperature and its good water retention capacity, which allowed greater contact with the seed.

Similarly, the commercial substrate plantmax ${ }^{\circledR}$ has aged manure, coconut fiber, rice husk and sawdust in its composition. These components have properties conducive to water retention and are not found in other 
substrates (Jeromini et al., 2018). Therefore, probably the highest percentage and germination speed rate observed for the var. Rubra (Tables 1 and 2), is not only due the proper combination between this substrate and temperature, but also to seed characteristics, such as thickness and tegument composition. While the sand does not maintain satisfactory level of humidity at high temperatures, it has a better efficiency in moderate thermal oscillations, since it presents uneven water retention and distribution, leaving the upper part dry (Melo et al., 2017).

Contrary to what was observed for H. sabdariffa, the most used substrate for Malvaceae seeds considered as Unconventional Food Plants (UFPs), such as Theobroma speciosum Willd. Ex Spreng (Varella et al., 2018) Theobroma grandiflorum (Willd. Ex Spreng.) K.Schum. (Moura et al., 2015) and Theobroma subincanum Mart. (Nascimento and Carvalho, 2012) includes sand, however, the temperature of $25^{\circ} \mathrm{C}$ is the most favorable to the percentage rate and speed of germination of these plant species. It can be predicted that the knowledge of the conditions that provide a fast and uniform germination of the $H$. sabdariffa var. Talo Roxo and Rubra seeds is useful for sowing purposes, since the homogeneous seedling development reduces nursery care, therefore seedlings will develop faster, promoting a more uniform growth in the field.

Regarding the evaluation of the development of H. sabdariffa seedlings (Table 3), it observed that the highest seedling lengths for var. Talo Roxo occurred in the substrate vermiculite at 25 and $30^{\circ} \mathrm{C}$. These results were statistically similar to those verified for seedlings from plantmax ${ }^{\circledR}$ and compost substrates at a temperature of $20-30{ }^{\circ} \mathrm{C}$. On the other hand, the best combinations that provided the best development for the var. Rubra seedlings length, occurred using sand, plantmax ${ }^{\circledR}$ and vermiculite and constant $35,25^{\circ} \mathrm{C}$ and alternating 20-30 ${ }^{\circ} \mathrm{C}$, temperatures, respectively (Table 3 ).

Table 3. H. sabdariffa var. Talo Roxo and var. Rubra seedling lenght $\left(\mathrm{cm}\right.$ seedling $\left.{ }^{-1}\right)$ from seeds subjected to different temperatures and substrates. São Luis, state of Maranhão, northeastern Brazil, 2018

\begin{tabular}{|c|c|c|c|c|c|}
\hline \multirow{2}{*}{ Substrates } & \multicolumn{5}{|c|}{ Temperatures $\left({ }^{\circ} \mathrm{C}\right)$} \\
\hline & 20 & 25 & 30 & 35 & $20-30$ \\
\hline \multicolumn{6}{|c|}{ H. sabdariffa var. Talo Roxo } \\
\hline Paper roll & $4.24 \mathrm{cC}$ & $10.88 \mathrm{bA}$ & $10.71 \mathrm{bA}$ & $9.13 \mathrm{bB}$ & $11.63 \mathrm{bA}$ \\
\hline On paper & $6.28 \mathrm{bB}$ & $6.53 \mathrm{cB}$ & $4.40 \mathrm{cC}$ & $5.67 \mathrm{cB}$ & $8.09 \mathrm{cA}$ \\
\hline Between sand & $6.22 \mathrm{bB}$ & $10.05 \mathrm{bA}$ & $9.50 \mathrm{bA}$ & $7.10 \mathrm{cB}$ & $11.07 \mathrm{bA}$ \\
\hline On sand & $5.77 \mathrm{bC}$ & $8.08 \mathrm{cB}$ & $5.80 \mathrm{cC}$ & $7.15 \mathrm{cB}$ & $10.50 \mathrm{bA}$ \\
\hline Plantmax ${ }^{\circledR}$ & $8.47 \mathrm{aD}$ & $12.48 \mathrm{aB}$ & $10.25 \mathrm{bC}$ & $13.36 \mathrm{aB}$ & $14.67 \mathrm{aA}$ \\
\hline Vermiculite & $8.66 \mathrm{aC}$ & $13.03 \mathrm{aA}$ & $13.04 \mathrm{aA}$ & $10.67 \mathrm{bB}$ & $11.90 \mathrm{bA}$ \\
\hline Compost & $6.96 \mathrm{bC}$ & $11.51 \mathrm{bB}$ & $12.20 \mathrm{aA}$ & $10.41 \mathrm{bB}$ & $13.08 \mathrm{aA}$ \\
\hline \multicolumn{6}{|c|}{ H. sabdariffa var. Rubra } \\
\hline Paper roll & $4.69 \mathrm{bC}$ & $5.68 \mathrm{dC}$ & $6.86 \mathrm{bB}$ & $5.35 \mathrm{cC}$ & $8.14 \mathrm{bA}$ \\
\hline On paper & $4.20 \mathrm{bB}$ & $3.81 \mathrm{eB}$ & $3.97 \mathrm{~dB}$ & $3.09 \mathrm{dC}$ & $7.32 \mathrm{cA}$ \\
\hline Between sand & $4.59 \mathrm{bD}$ & $6.04 \mathrm{dC}$ & $6.70 \mathrm{bB}$ & $8.30 \mathrm{aA}$ & $7.01 \mathrm{cB}$ \\
\hline On sand & $4.07 \mathrm{bC}$ & $4.03 \mathrm{eC}$ & $5.40 \mathrm{cB}$ & $3.23 \mathrm{dC}$ & $8.00 \mathrm{bA}$ \\
\hline Plantmax $^{\circledR}$ & $6.41 \mathrm{aC}$ & $8.44 \mathrm{bB}$ & $7.94 \mathrm{aB}$ & $6.89 \mathrm{bC}$ & $9.55 \mathrm{aA}$ \\
\hline Vermiculite & $6.26 \mathrm{aC}$ & $9.66 \mathrm{aA}$ & $7.56 \mathrm{aB}$ & $7.01 \mathrm{bB}$ & $8.81 \mathrm{aA}$ \\
\hline Compost & $5.21 \mathrm{bC}$ & $7.22 \mathrm{cB}$ & $6.90 \mathrm{bB}$ & $8.00 \mathrm{aA}$ & $8.30 \mathrm{bA}$ \\
\hline $\mathrm{CV}(\%)$ & \multicolumn{2}{|c|}{ var.Talo Roxo 12.54} & \multicolumn{2}{|c|}{ var. Rubra 9.49} & \\
\hline
\end{tabular}

Note. Means followed by the same letter (lowercase in the column and uppercase in the row) do not differ by the Scott-Knott test at $5 \%$ probability.

The highest $H$. sabdariffa var. Talo Roxo seedling dry mass content was observed on paper roll at $25^{\circ} \mathrm{C}$ (Table 4), although this result was similar at $5 \%$ probability level by the Scott-Knott test to those obtained on sand at $20{ }^{\circ} \mathrm{C}$, plantmax ${ }^{\circledR} 30{ }^{\circ} \mathrm{C}$ and vermiculite at $35{ }^{\circ} \mathrm{C}$. With respect to $H$. sabdariffa var. Rubra, the treatment combinations that favored the seedlings dry mass accumulation were paper roll at $25^{\circ} \mathrm{C}$; between sand at $20^{\circ} \mathrm{C}$; compost at $35{ }^{\circ} \mathrm{C}$; on sand at $25^{\circ} \mathrm{C}, 35^{\circ} \mathrm{C}$ and $20-30{ }^{\circ} \mathrm{C}$; plantmax ${ }^{\circledR}$ in the thermal range between $20^{\circ} \mathrm{C}$ and $30^{\circ} \mathrm{C}$ and in vermiculite in all thermal conditions, with the exception of the alternating temperature of $20-30^{\circ} \mathrm{C}$. 
Table 4. H. sabdariffa var. Talo Roxo and var. Rubra seedling dry mass (g. seedling ${ }^{-1}$ ) from seeds subjected to different temperatures and substrates. São Luis, state of Maranhão, northeastern Brazil, 2018

\begin{tabular}{llllll}
\hline \multirow{2}{*}{ Substrates } & \multicolumn{4}{c}{ Temperatures $\left({ }^{\circ} \mathrm{C}\right)$} \\
\cline { 2 - 6 } & 20 & 25 & 30 & 35 & $20-30$ \\
\hline P. sabdariffa var. Talo Roxo & & & & \\
On paper & $0.276 \mathrm{bC}$ & $0.739 \mathrm{aA}$ & $0.405 \mathrm{cB}$ & $0.323 \mathrm{aC}$ & $0.030 \mathrm{bD}$ \\
Between sand & $0.158 \mathrm{cA}$ & $0.174 \mathrm{cA}$ & $0.273 \mathrm{dA}$ & $0.214 \mathrm{bA}$ & $0.035 \mathrm{bB}$ \\
On sand & $0.245 \mathrm{bB}$ & $0.452 \mathrm{bA}$ & $0.527 \mathrm{bA}$ & $0.306 \mathrm{aB}$ & $0.156 \mathrm{aC}$ \\
Plantmax & $0.373 \mathrm{aA}$ & $0.413 \mathrm{bA}$ & $0.172 \mathrm{~dB}$ & $0.090 \mathrm{cC}$ & $0.024 \mathrm{bC}$ \\
Vermiculite & $0.057 \mathrm{cC}$ & $0.268 \mathrm{cB}$ & $0.637 \mathrm{aA}$ & $0.210 \mathrm{bB}$ & $0.177 \mathrm{aB}$ \\
Compost & $0.117 \mathrm{cB}$ & $0.180 \mathrm{cB}$ & $0.222 \mathrm{~dB}$ & $0.319 \mathrm{aA}$ & $0.206 \mathrm{aB}$ \\
H. sabdariffa var. Rubra & $0.308 \mathrm{bA}$ & $0.215 \mathrm{cB}$ & $0.270 \mathrm{dA}$ & $0.156 \mathrm{bB}$ & $0.192 \mathrm{aB}$ \\
Paper roll & & & & \\
On paper & $0.149 \mathrm{bB}$ & $0.156 \mathrm{bB}$ & $0.349 \mathrm{aA}$ & $0.140 \mathrm{bB}$ & $0.101 \mathrm{cB}$ \\
Between sand & $0.162 \mathrm{bA}$ & $0.150 \mathrm{bA}$ & $0.101 \mathrm{cA}$ & $0.065 \mathrm{bA}$ & $0.032 \mathrm{cA}$ \\
On sand & $0.396 \mathrm{aA}$ & $0.280 \mathrm{aB}$ & $0.236 \mathrm{bC}$ & $0.190 \mathrm{aC}$ & $0.107 \mathrm{cD}$ \\
Plantmax & $0.172 \mathrm{bA}$ & $0.273 \mathrm{aA}$ & $0.242 \mathrm{bA}$ & $0.220 \mathrm{aA}$ & $0.300 \mathrm{aA}$ \\
Vermiculite & $0.317 \mathrm{Aa}$ & $0.313 \mathrm{aA}$ & $0.375 \mathrm{aA}$ & $0.164 \mathrm{aB}$ & $0.137 \mathrm{cB}$ \\
Compost & $0.324 \mathrm{Aa}$ & $0.234 \mathrm{aA}$ & $0.283 \mathrm{aA}$ & $0.237 \mathrm{aA}$ & $0.120 \mathrm{cB}$ \\
CV $(\%)$ & $0.184 \mathrm{Ba}$ & $0.129 \mathrm{bA}$ & $0.227 \mathrm{bA}$ & $0.225 \mathrm{Aa}$ & $0.188 \mathrm{bA}$ \\
\hline
\end{tabular}

Note. Means followed by the same letter (lowercase in the column and uppercase in the row) do not differ by the Scott-Knott test at $5 \%$ probability.

Lighter substrates, such as sand and vermiculite, allow greater gas exchange and better drainage, reducing the physical barrier to initial seedling development (Jeromini et al., 2018), as observed for P. volubilis by Silva et al. (2016). It is noteworthy that the plantmax ${ }^{\circledR}$ substrate has macro and micronutrients in its composition, as well as suitable particle quality, these led to favorable results for all $H$. sabdariffa seed evaluated variables, because just after the $H$. sabdariffa seed germination and emission of the primary roots, immediately began the process of absorption of the nutrients present in this substrate and its mobilization to the seedling structures, promoting their development and dry mass accumulation.

These results are similar to those reported by Barrozo et al. (2014) where the combination between vermiculite and the temperature of $30^{\circ} \mathrm{C}$ favored the growth of Inga laurina (Sw.) Willd, a species cited by Barreira et al. (2015) as one of the Unconventional Food Plants (UFPs), most used as food by the communities of the Amazon biome in Brazil. The good water retention capacity of plantmax ${ }^{\circledR}$ and/or vermiculite substrates is efficient, when combined with temperatures between 20 and $30{ }^{\circ} \mathrm{C}$, since it is possible to predict that under these conditions, according to Marcos Filho (2015b) water allows the diffusion of hormones and consequently activation of enzymatic systems, favoring the digestion, translocation and assimilation of the reserves, resulting in embryo development and seedling growth.

\section{Conclusion}

For germination and vigor tests of Hibiscus sabdariffa var. Talo Roxo seeds the paper roll substrate is recommended at temperatures of 25 or $35^{\circ} \mathrm{C}$ and for var. Rubra, plantmax ${ }^{\circledR}$ substrate is recommended at $25{ }^{\circ} \mathrm{C}$ and plantmax ${ }^{\circledR}$ and vermiculite substrates at temperatures of 25 or $20-30{ }^{\circ} \mathrm{C}$, respectively.

\section{References}

Barreira, T. F., Paula Filho, G. X., Rodrigues, V. C. C., Andrade, F. M. C., Santos, R. H. S., Priore, S. E., \& Pinheiro-Sant'ana, H. M. (2015). Diversity and equivalence of unconventional food plants in rural zone of Viçosa, Minas Gerais, Brazil. Revista Brasileira de Plantas Medicinais, 17(4), 964-974. https://doi.org/ 10.1590/1983-084X/14_100

Barrozo, L. M., Alves, E. U., Silva, R. S., Anjos Neto, A. P., Santos Neta, M. M. S., \& Silva, B. F. (2014). Substrates and temperatures to germination and vigor test Inga laurina (Sw.) Willd. Seeds. Bioscience Journal, 30(1), 252-261. 
Costa, R. I., Bonnlaender, B., Sievers, H., Pischel, I., \& Heinrich, M. (2014). Hibiscus sabdariffa L.-A phytochemical and pharmacological review. Food Chemistry, 165(2), 424-443.

Djaeni, M., Kumoro, A. C., Sasongko, S. B., \& Utari, F. D. (2018). Drying rate and product quality evaluation of roselle (Hibiscus sabdariffa L.) calyces extract dried with foaming agent under different temperatures. International Journal of Food Science, 11(4), 1-8. https://doi.org/10.1155/2018/9243549

Formagio, A. S. N., Ramos, D. D., Vieira, M. C., Ramalho, S. R., Silva, M. M., Zárate, N. A. H., ... Carvalho, J. E. (2015). Phenolic compounds of Hibiscus sabdariffa and influence of organic residues on its antioxidant and antitumoral properties. Brazilian Journal of Biology, 75(1), 69-76. https://doi.org/10.1590/1519-6984.07413

Galal, A. (2017). Physico-chemical changes in karkade (Hibiscus sabdariffa L.) seedlings responding to salt stress. Acta biologica Hungarica, 68(1), 73-87. https://doi.org/10.1556/018.68.2017.1.7

Guardiola, S., \& Mach, N. (2014). Therapeutic potential of Hibiscus sabdariffa: A review of the scientific evidence. Endocrinología y Nutrición, 61(5), 274-95. https://doi: 10.1016/j.endonu.2013.10.012

Jeromini, T. S., Barbosa, A. S. V., Silva, G. Z., \& Martins, C. C. (2018). Substrate and seed sowing position on the production of Plukenetia volubilis L. seedlings. Revista Brasileira de Engenharia Agrícola e Ambiental, 22(6), 396-400. https://doi.org/10.1590/1807-1929/agriambi.v22n6p396-400

Leal, M. L., Alves, R. P., \& Hanazaki, N. (2018). Knowledge, use, and disuse of unconventional food plants. Journal of Ethnobiology and Ethnomedicine, 14(6), 1-9. https://doi.org/10.1186/s13002-018-0209-8

Lima, I. E. O., Nascimento, L. A. M., \& Silva, M. S. (2016). Comercialização de plantas medicinais no município de Arapiraca-AL. Revista Brasileira de Plantas Medicinais, 18(2), 462-472. https://doi.org/ 10.1590/1983-084X/15_201

Maguire, J. D. (1962). Speed of germination-aid selection evolution for seedling emergence and vigor. Crop Science, 2(2), 176-177.

MAPA (Ministério da Agricultura, Pecuária e Abastecimento). (2009). Regras para Análise de Sementes (p. 395). Secretaria de Defesa Agropecuária. Brasília: MAPA/ACS.

Marcos Filho, J. (2015a). Fisiologia de sementes de plantas cultivadas (p. 659). Londrina: ABRATES.

Marcos Filho, J. (2015b). Seed vigor testing: an overview of the past, present and future perspective. Scientia Agricola, 72(4), 363-374.

Melo, P. A. F. R., Alves, E. U., Anjos Neto, A. P., Medeiros, R. L. S., Ferreira Junior, D. C., Leite, W. S., ... Bezerra, A. K. D. (2016). Temperature and pre-germinative treatments for overcoming Acacia farnesiana L. seeds dormancy. African Journal of Agricultural Research, 11(37), 3548-3553. https://doi.org/10.5897/ AJAR2016.11493

Melo, P. A. F. R., Cavalcanti, M. I. P., Alves, E. U., Martins, C. C., \& Araújo, L. R. (2017). Substrates and temperatures in the germination of Eriotheca gracilipes seeds. Revista Ciência Agronômica, 48(2), 303-309. https://doi.org/10.5935/1806-6690.20170035

Moura, E. A., Chagas, C. P., Moura, M. L. S., Souza, O. M., \& Chagas, E. (2015). A Emergence and early development of cupuassu seedlings grown on different substrates and under different conditions of shade. RevistaAgro@mbiente, 9(4), 405-413.https://doi.org/10.18227/1982-8470ragro.v9i4.2597

Nakagawa, J. (1999). Testes de vigor baseados no desempenho das plântulas. In F. C. Krzyzanoski, R. D. Vieira, \& J. B. França Neto (Eds.), Vigor de sementes: Conceitos e testes (Cap. 2, pp. 1-24.) Londrina: ABRATES.

Nascimento, W. M. O., \& Carvalho, J. E. U. (2012). Sensibility of "Cupuí" Theobroma subincanum seeds to reduction of moisture content and low temperature storage. Revista Brasileira de Fruticultura, 34(3), 915-920. https://doi.org/10.1590/S0100-29452012000300034

Nasrabadi, Z. M., Zarringhalami, S., \& Ganjloo, A. (2018). Evaluation of chemical, nutritional and antioxidant characteristics of roselle (Hibiscus sabdariffa L.) Seed. Nutrition and Food Sciences Research, 5(1), 41-46. https://doi.org/10.29252/nfsr.5.1.41

Nzikou, J. M., Bouanga-Kalou, G., Matos, L., Ganongo-Po, F. B, Mboungou-Mboussi, P. S., Moutoula, F. E., ... Desobry, S. (2011). Characteristics and nutritional evaluation of seed oil from Roselle (Hibiscus sabdariffa L.) in Congo-Brazzaville. Current Research Journal of Biological Sciences, 3(2), 141-146.

Riaz, G., \& Chopra, R. (2018). A review on phytochemistry and therapeutic uses of Hibiscus sabdariffa L. Biomedicine \& Pharmacotherapy, 102(3), 575-586. https://doi.org/10.1016/j.biopha.2018.03.023 
Silva, G. S., Rêgo, A. S., \& Leite, R. R. (2014). Diseases of roselle in the state of Maranhão, Brazil. Summa Phytopathologica, 40(4), 378-380. https://doi.org/10.1590/0100-5405/2002

Silva, G. Z., Vieira, V. A. C., Boneti, J. E. B., Melo, L. F., \& Martins, C. C. (2016). Temperature and substrate on Plukenetia volubilis L. seed germination. Revista Brasileira de Engenharia Agrícola e Ambiental, 20(11), 1031-1035. https://doi.org/10.1590/1807-1929/agriambi.v20n11p1031-1035

Singh, P., Khan, M., \& Hailemariam, H. (2017). Nutritional and Health Importance of Hibiscus Sabdariffa: A Review and Indication for Research Needs. Journal of Nutritional Health \& Food Engineering, 6(5), 2-12.

Varella, T. L., Rossi, A. A. B., Souza, M. D. A., Silveira, G. F., Cochev, J. S., Toledo, J. J., \& Silva, C. J. (2018). Populational structure and spatial distribution of Theobroma speciosum Willd. Ex Spreng IN Northern of Mato Grosso State. Ciência Florestal, 28(1), 115-126. https://doi.org/10.5902/1980509831589

\section{Copyrights}

Copyright for this article is retained by the author(s), with first publication rights granted to the journal.

This is an open-access article distributed under the terms and conditions of the Creative Commons Attribution license (http://creativecommons.org/licenses/by/4.0/). 